\title{
Promoting the Diamond Suite and President Suite of Rich Palace Hotel Using a Promotional Video
}

\author{
Poh Vania Lokita $P$ \\ English Department, Faculty of Letters, Petra Christian University \\ Surabaya, East Java, Indonesia \\ e-mail: Pohvania@gmail.com
}

\begin{abstract}
The main problem that Rich Palace Hotel is currently facing is the Diamond suites and Platinum President suites are not selling very well. The occupancy of both rooms are very low which is only $5 \%-8 \%$ per month. Therefore, making a promotional tool with video form would be the right solution to solve the problem. By watching promotional video customers will know more about Diamond suites and President suites, because promotional video contains information that can increase customers awareness of the The Diamond suite and President suite. It can also become the tool for the sales and marketing team to offer both rooms in order to increase the occupancy level. The video will show about the benefits of staying in Diamond Suites or Platinum President Suites compared to staying at the Deluxe room.
\end{abstract}

Keywords: promotional video, promotional tool,hotel.

\section{INTRODUCTION}

The company where I had my internship is Rich Palace Hotel. Rich Palace Hotel is thenewest 5-star hotel located in west Surabaya. It is run by So-Asia Group (PT. Sinar Anugrah Jaya) and owned by Mr.Tjakra. Rich Palace Hotel has been running for two years as of now, with the total of 205 rooms. They offer varieties of rooms for the guests, starting from Deluxe, Executive, Diamond Suite, and President Suite. Not only accomodating bedrooms, Rich Palace Hotel also offers six types of meeting rooms which include one Onyx room, two Jade rooms, and three Saphire rooms that comes in many sizes. The hotel also has a semi-ballroom called Dragon Sky Ballroom which is available for big events. Rich Palace Hotel welcomes their guests with their friendly staffs to make them comfortable in staying at the hotel. Within three month of me doing internship in Rich Palace Hotel, I have found a problem concerning the company. The main problem that Rich Palace Hotel currently facing is the Diamond suites and Platinum President suites are not selling very well. The occupancy of both rooms are very low which is only $5 \%-8 \%$ per month. Compared with Deluxe rooom, Deluxe room is well sold with occupancy per month 8090\%.The sales and marketing person can not sell both President suites and Diamond suites well because they do not have the tool about Diamond suite and President suite. Besides that, most of the customers do not know that Rich Palace Hotel has President suites and Diamond suites. Rich Palace Hotel sales kit and brochure mostly contain information about the most standart room Deluxe and Executive rooms. The left information is about President suites and Diamond suites.

The problem of the project is how to increase the monthly occupancy of President suite and Diamond suite. Therefore, promotional video is expected to increase the monthly occupancy of President suite and Diamond suite. The promotion video will make the customers know more about Diamond suites and President suites also will facilitate the sales and marketing team to sell Diamond suites and President suites. There are some theories that I used to make this project. First, Definition of promotion, based on Semenik (2002, p.7), promotion is "the communication process in the marketing that is used to create a favorable predisposition toward a brand of product or service, an idea, or even a person. Those theories really help me in doing project, promotional video.

\section{METHODS}


There are several steps that I did to get the approve from the board of examiner for my Business Communication Final Project (BCFP) proposal. After finishing my internship, I made a proposal in which I want to discuss about the problems I found at Rich Palace Hotel Surabaya which is related to Sales and Marketing team. After I had gotten the approve to apply my project at Rich Palace Hotel Surabaya, I made a proposal for the board examiners. Making a Google survey is the next step that I did for making sure the General Manager, Michele Meoni to approve my project which is promotional video. I spread the google survey to ten staff of Rich Palace Hotel. This is the questions that I spread:

- What kind of tools do you usually bring when you are doing a sales call for selling Rich Palace Hotel products?

- Does the sales tool you have help you in sales call? How so?

- Do you think by using a video for sales tool will make it more intresting and helpful? why

- What kind of products do we need to feature in the video?

The results of my survey reached a conclusion that making a promotional video can be effective than the last sales kit. 10 out of the 10 staffs agreed that a promotional video is more effective and fun. They said that the last sales kit is boring because it came out in a written form. They also wanted to include some information about Diamond suite and President suite than the Deluxe and Executive room in the promotional video. The last sales kit only contains information about Deluxe and Executive room, so they hope in the next sales tool kit both rooms will not be included.

Next,I made a letter of agreement or a contract for them while waiting for their answer. After two weeks, I finally had the opportunity to meet the General Manager again. He asked me about my project and what will I feature on the video. Finally, he agreed to let me do my project at the company and I showed him the contract. Mr. Michel Meoni asked for more time to read and discuss the contract with the team.

The final step, I waited for more than 2 weeks due to Mr. Meoni's trip from Italy. I got a call to meet him in order to discuss the contract. We talked about 3 hours and he asked me about the detail in every package that I wrote in my proposal. There are two choices that I offered to Rich Palace Hotel Surabaya The details will be explained on following table:

\begin{tabular}{|c|c|c|c|c|}
\hline \multicolumn{5}{|c|}{ II } \\
\hline Components & Quanti & & Unit Price & Cost \\
\hline Video maker+Assistant & 2 Pax & $\mathrm{X}$ & Rp $1,500,000,-$ & Rp 3,000,000,-- \\
\hline Professional models & 2 Pax & $\mathrm{X}$ & Rp $1,250,000,-$ & Rp 2.500,000,- \\
\hline Transport+foods & \begin{tabular}{l|l}
4 & Pax \\
\end{tabular} & $\mathrm{X}$ & $\mathrm{Rp} \quad 250,000,-$ & Rp 1.000.000,- \\
\hline Total & & & & $\operatorname{Rp} 6,500,000,-$ \\
\hline
\end{tabular}

The first step to make the promotional video is finding the selling points of the Diamond suite and President suite and comparing them with the Deluxe room. I collected the data of Deluxe room from the last sales kit. I also asked the staffs about the size of room, price and facilities that customers will get by staying in the Deluxe room. After that, I continued in collecting some data of the Diamond suites. After I have compiled the data, I compared the Deluxe room and Diamond suite. By comparing them, I understood the uniqueness and selling points of the Diamond suite. Next, I collected the data about President suite and did some comparing between Diamond suite and President suite to understand the selling points of the latter. To show the selling points and uniqueness, I categorized in to three parts; Room size, facilities and privacy. Next is the explanation of the selling points of each room.

\begin{tabular}{|l|l|l|l|}
\hline $\begin{array}{l}\text { Criteria of } \\
\text { comparison }\end{array}$ & Deluxe room & Diamond Suites & $\begin{array}{l}\text { Platinum President } \\
\text { Suites }\end{array}$ \\
\hline
\end{tabular}




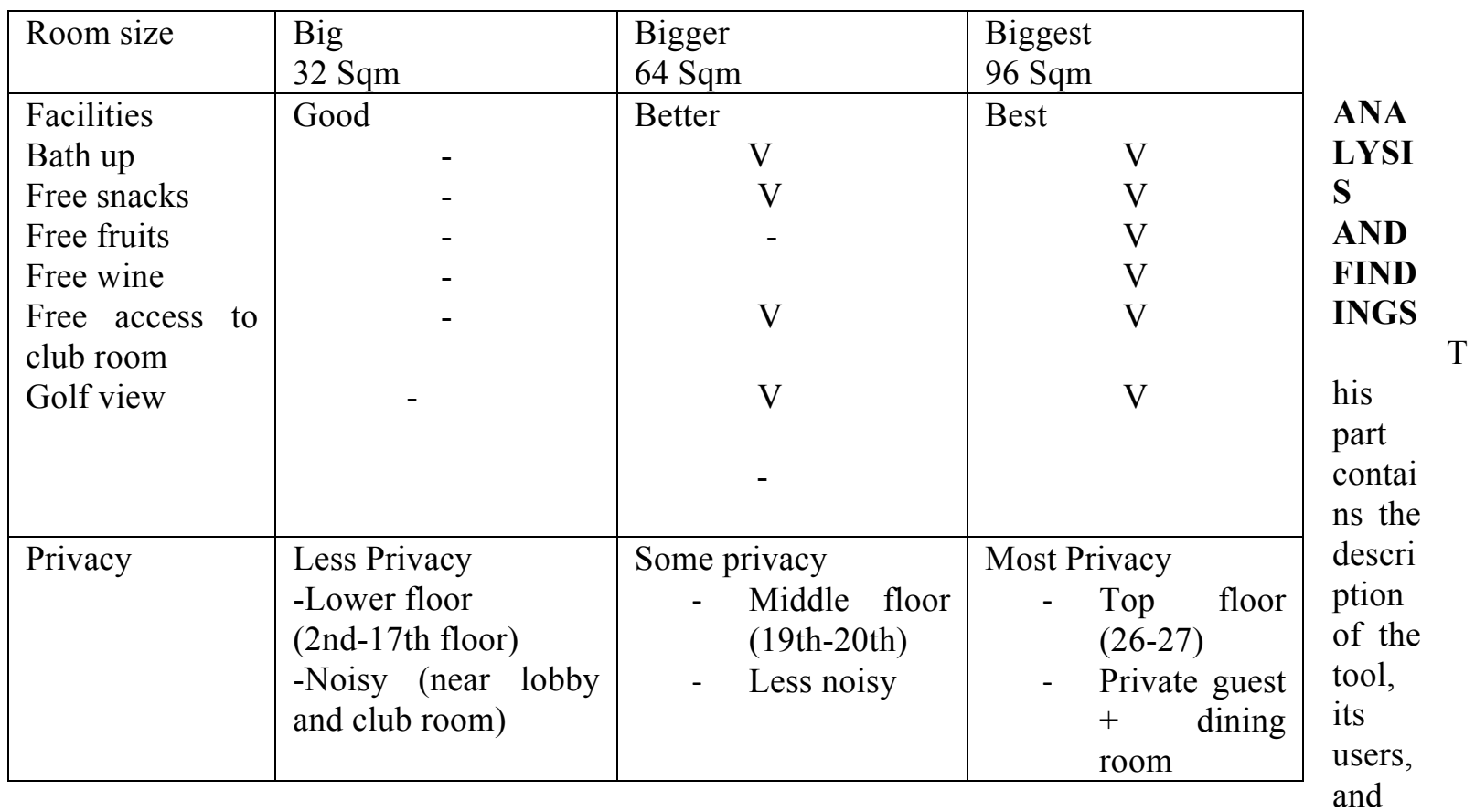

its purpose for the company. The product is called "Promotional Video of Diamond suite and President suite Rich Palace Hotel Surabaya". In this video, there are four components. First, the outside building and the lobby. Second, Exclusive Dynasty Lounge. Third, Diamond suite and the last is President suite. I applied the theory of The brand expression defined according to (Gelder 2003, p.30) "The brand expression consists of three elements: the brand's positioning, its identity and its personality. Brand positioning consist of how the brand is better than different from its competition. It is based on fairly functional aspects of products and services. The brand identity consist of what the brand stands for and of aspects that have to do with the brand's legacy. Using that theory, I can find the USPs that are classified into three parts room size, facility and privacy for both Diamond suite and president suite. I only shoot Diamond suite and President suite. In order to the organize the video, I use the order of importance from not-so really important to the most important. The first scene in this video, I choose " The outside building and the lobby" because it is not really containing important information. This scene also has function as the opening scene of this promotional video. Second, the scene is about "Exclusive Dynasty Lounge". I put in the second because this scene is pretty important to show to the customers. In this scene, it contains the information about Exclusive Dynasty Lounge that both customers of Diamond suite and President suite can use this lounge for free. The third scene is considered as important where it shows the "Diamond suite". In this scene I show the uniqueness about this room, which are spacious living room, room size, free mini bar, free wine and deluxe bathtub. The last and the most important scene is about "President suite". I put in the last scene of the video because this is the climax of the promotional video and the most exclusive room at Rich Palace Hotel. In this scene, I show the uniqueness about this room, which are the most spacious living room, free wine, free mini bar, free fruits, golf view and deluxe jacuzzi.

The target market of this promotional video is businessmen who travel around for work, CEOs, travelers, and people who work in the governments. By watching the promotional video, the customers who did not know at about Diamond suite and President suite at first will be aware of that type of room. Other than that, regular customers that usualy stay at the Deluxe room are expected to try the upgraded version of their rooms which are the Diamond suite or even the best one, the President suite. In addition, by giving a promotional video to the travel agencies, it will help Rich Palace Hotel to promote Diamond suite and President suite well.

This promotional video will give three advantages to Rich Palace Hotel Surabaya. First, the promotional video will be a tool for Sales and Marketing to help them promoting Diamond suite and President suite. Second, the promotional video can increase the customers' awareness to know video know more about Rich Palace Hotel Surabaya products, especially Diamond suite and 
President suite. The last advantage is the promotional video will help the regular guests that usually use Deluxe room to upgrade their room into Diamond suite and President Suite.

For the Business Communication Final Project, I decided to make a promotional video. The reason why I make this promotional video is because the content in the video attract customers and make them have better understanding about Rich Palace products specially Diamond Suite and President suite. Then, doing a promotion through a video is more effective and fun compared to the last sales kit where it came in written form. Therefore, it is essential to make this promotional video to help the Sales and Marketing team for selling both Diamond suite and President suite.

I applied this theory based on medium.com there are 8-steps for making good video. This steps are really helpful for starting make a promotional video for Rich Palace Hotel Surabaya. This theory helps me to get the model that fits in the video, find the theme of the video and write a good storyboard. The models that I used for promotional video are Vivian Tania and James Immanuel. The female model is Vivian Tania, a freshman in her $2^{\text {nd }}$ semester from Universitas Surabaya who majors in Management Business. She is currently 20 years old and is the finalist of Miss Jawa Timur 2017. In addition, last year, she was included in the big 10 of Miss Indonesia 2017. The reason why I choose her as my model for the promotional video is because she has the basic in acting and modeling. She understands on how to create a classy and luxurious vibe in front of the camera because of her training in modeling and quarantine during her Miss Indonesia pageant. In the video, Vivian uses make-up. black-short dress and high heels. Through her outfit, I put Vivian for the "President suites" scene because her appearance can create luxurious images for the most exclusive room.

The male model is James Immanuel. He is 22nd years old and a senior in Petra Christian University majoring in Marketing. Besides studying in Petra Christian University, he also works as a freelance model. I choose him as my male model because of his proportional weight and height as a model. James uses casual shirt, long pants, belt and pantofel in this promotional video. By using a casual outfit, I decided to put James as a businessman in the "Diamond suite" because the Diamond suite type of room is usually used by businessmen for their business trips.

For the content of promotional video, I choose three important components, such as the building and the lobby of the hotel, the uniqueness of Diamond suite and the uniqueness of President suite. First, I decided to use those components because they contain a lot of information needed by the potential customers in order to know more about Diamond suite and President suite. Customers are usually do not know about both Diamond suite and President suite. Those components are considered as very important to be included in promotional video.

In addition, the order of the components included in the promotional video also becomes one of the important points that will be my consideration in making this promotional video. Based on the order of importance from not-so important into the most important scene, I put the scene " The Outside Building and the Lobby" in the first order because the scene only shows the image of Rich Palace from outside. It will help customers to know the impression of the building of Rich Palace Hotel Surabaya. After that, I show the scene in the lobby to show what kind of atmosphere inside the hotel.

Second, I put the scene about "Exclusive Dynasty Lounge". I put this in the second scene because it is pretty important for the customers. This scene does not only show the image of the Exclusive Dynasty Lounge, but also the subtitle about the information of this room. The images and the information help the customers to be aware that Exclusive Dynasty Lounge is one of the benefits for Diamond suite and President suite guests. The scene that I show the models, James and Vivian, doing activity inside Exclusive Dynasty Lounge. I asked them to eat and have a leisure time in the lounge to send my message about about Exclusive Dynasty Lounge for the customers.

Third, I put the scene about "Diamond suite" which is important in this promotional video. This scene shows the image and information about the uniqueness of Diamond suite. This will make the customers understand the advantages of staying in the Diamond suite. The scene shows James enjoying the spacious living room, drinking free wine, and turning on the Deluxe bathtub to show the uniqueness of Diamond suite.

Last, I put the scene about "President suite" in last scene beacuse it is the climax of the video or I can say the most important scene of this promotional video. Vivian, the female model is acting to drink free wine, enjoy the spacious living room with the view of the golf field and pour 
the bubble bath in the Jacuzzi bathtub. This is to show the uniqueness and selling points of the President suite.

Based on the order of importance, the customers who watch this promotional video will have an impression of getting more luxurious atmosphere in the end of video. Starting from The building and lobby of the hotel, Executive Dynasty Lounge, Diamond suite and the last is President suite

\section{CONCLUSION}

The main problem that Rich Palace Hotel currently faces is the Diamond suites and Platinum President suites are not selling very well. The occupancy of both rooms is very low which is only 5\%-8\% per month. Compared with Deluxe rooom, Deluxe room is well sold with occupancy per month $80-90 \%$.The sales and marketing person cannot sell both President suites and Diamond suites well because they do not have the sales tool about Diamond suite and President suite. Besides that, most of the customers do not know that Rich Palace Hotel has President suites and Diamond suites. Rich Palace Hotel sales kit and brochure mostly contain information about the most standard room Deluxe and Executive rooms. The left information is about President suites and Diamond suites.

First, I made and presented the proposal then negotiate the price. Next, I made the concept and script which went through a lot of revisions. I did some research and interviews in order to get some of the unique selling points and write the content. Next, I had to explain my idea to the staffs of Rich Palace Hotel Surabaya so that the content of the promotional video will go well. Finally, after I got all the data, I started to plan for the shooting and subtitles. I arranged the concept, contents and hired the models. The draft that I made was helped by my advisor to ensure it was the best that I could give to the Rich Palace Hotel Surabaya.

The promotional video is hoped to be a beneficial tool for the Rich Palace Hotel Surabaya. The Sales and Marketing team can use the promotional video to give them facility in selling the Diamond suite and President suite well. Furthermore, the promotional video will help the customers who watch this video to know more about Rich Palace Hotel Surabaya products, especially Diamond suite and President suite. The last advantage is, the promotional video will help the regular guests that ususally use Deluxe room to upgrade their room into Diamond suite and President Suite.

\section{ACKNOWLEDGEMENT}

Firstly, I would like to give my humblest gratitude to Jesus Christ for guiding me throughout the process of writing this thesis and also during my study in Petra Christian University. There were numerous times when I felt lost and given up hope, but through the strength of prayers and His guidance I continued to endure and strive to aim for the best. I am very thankful for His blessings because I would not have been able to finish this thesis without Him.

I also would like to thank all lecturers in the English Department for their devoted time and energy teaching me in class and outside class. Personally, I would like to give my appreciation to my advisor, Drs. Jusuf Ibrahim, M.TSEL, for his passionate guidance and support which had helped me in writing and fishing this thesis. I am really grateful to have him as my advisor.

Furthermore, I would like to thank my family, especially my mother Christiana Gunawan, my father Poh Sing Liong, My beloved grandmother Alm.Po Siem Kien Nio, my one and only sibling Poh Vito Aprillio Pratomo. for their enormous support and love during my study in English Department. Thank you for my dad for believing me and my mom for encouraging me all this time.

I also would like to thank all members of Altoro Spanish Gatrobar. General Manager, Tony Torres, Assistant General Manager, Andreas Immanuel and my Marketing team,Fedora, Gaby, Evelina and Melinda for understanding and supporting me in the process of making this project and BCFP.

Last but not least, I would like to thank all my friends in Petra Christian University, especially English Department student batch 2014 for their support for my thesis Elysia, Melinda, Christina, Ivena, Alvin, Jacqueline,Venny,Kevin, Sherin, Jofe and Monica. I will always treasure the laughs, good times, and bad times we have shared and faced together. Also, I would like to extend a special thank you for my super best friends, Marcella Evelyn, Gery Ivander, Samantha 
Pradiptan, Chyntya Rani who are always there for me when I need help and support during the process of finishing this thesis.

\section{REFERENCES}

Semenik, Richard J. 2002. Promotion and Integrated Marketing Communication. Canada: Dave Shaut.

Magurie,Annie. (2016). Retrieved from

$<$ https://medium.com/swlh/how-to-create-promotional-video-707fa7a63019> 